\title{
THE ROLE OF FINANCIAL TECHNOLOGY (FINTECH) IN ZIS
} MANAGEMENT TO OVERCOME POVERTY

\section{A. Zuliansyah ${ }^{1}$}

Universitas Islam Negeri Raden Intan, Bandar Lampung, Indonesia zuliansyah@ radenintan.ac.id

\author{
Dimas Pratomo ${ }^{2}$ \\ Universitas Islam Negeri Raden Intan, Bandar Lampung, Indonesia \\ dimaspratomo@radenintan.ac.id \\ Okta Supriyaningsih ${ }^{3}$ \\ Universitas Islam Negeri Raden Intan, Bandar Lampung, Indonesia \\ oktasupriyaningsih@ radenintan.ac.id
}

\begin{abstract}
Indonesia's zakāh potential is large enough to overcome poverty, but the Indonesian population living below the poverty line is still quite high, reaching 25.95 million people. These data indicate that the large potential of zakāh has not contributed enough to poverty alleviation in Indonesia. To increase zakäh collection, the Zakāh Management Organization (OPZ) innovates by using fintech in its management. The study aims to see how the role of fintech in managing ZIS is to contribute to poverty alleviation in Indonesia. The method used is a qualitative method by analyzing data and facts obtained from the object under study namely; BAZNAS Central Jakarta and BAZNAS Prov. DIY 2020 descriptively and in detail. The results of the study indicate that fintech has played a significant role in increasing zakăh collection over the last five years. It can be seen from the growth of $z a k \bar{a} h$ distribution from 2015 to 2019 experienced a significant increase, reaching an average of $40.93 \%$.
\end{abstract}

Keywords: Fintech, Zakāh, ZIS Management, Poverty 


\section{INTRODUCTION}

Zakāh is one of the obligations that must be fulfilled by all Muslims (Atabik, 2016; Fitri, 2017). Zakāh is one of the public instruments for alleviating poverty (Rahman, 2019; Safitri, 2018). Zakāh has a strategic role in removing people from the abyss of poverty and building a strong country (Salim, 2002). If the potential can be collected properly, of course $z a k \bar{a} h$ can be an optimal alternative solution in reducing the burden of the state budget to overcome poverty and improve people's welfare.

Poverty is a common problem and needs to be solved jointly by various parties, and the government has a big role in poverty alleviation. Poverty eradication can be done by optimizing zakāh management (Afdali et.al., nd; Nurwati \& Hendrawati, 2019). The existence of zakāh as one of the pillars of Islam is not only interpreted as a mere worship that is required of every Muslim for those who have met the requirements, but also more than that, namely as a system of distributing property among Muslims, from the rich to the poor. Thus, zakāh is able to eliminate socio-economic disparities in society (Qodir, 1998; Nurhadi, 2020).

In reality, various challenges hinder the collection and management of zakāh in Indonesia today (Restra-Baznas-2016-2020, nd). First, public awareness of tithing is still relatively low. The condition is coupled with the obligation of zakāh which is still voluntary in the statutory regulations in Indonesia. Second, there is a general phenomenon that people tend to pay zakāh directly to mustahiq. Third, public trust in zakāh management institutions is still low. All of these factors have an influence on the low number of zakāh management carried out by BAZNAS, Provincial BAZNAS, Regency/City BAZNAS, and LAZ from the available $z a k \bar{a} h$ potential.

In order to overcome these obstacles, especially the phenomenon of people who tend to pay zakāh directly to mustahiq, BAZNAS makes innovations to make it easier for people to pay zakāh. The innovation carried out by BAZNAS is the use of fintech in collecting zakāh funds. Fintech is a technology-based system, making it easier for people to pay zakāh. In the media Republika 2019, the National Amil Zakāh Agency targets 30 percent of the total zakāh collection in 2020 to come from digital channels. This target is in line with the trend of developing financial technology (Fintech) which is increasingly accessible to the public (Nasrullah, 2019). 
Partnerships with fintech providers are a must in today's era when smartphones are increasingly mushrooming and are owned by many Indonesians, both in big cities and remote areas. Then BAZNAS also implements online payment services such as internet banking and SMS banking (Baznas, 2021). Therefore, it is expected that after the existence of Fintech, zakäh collection can be managed optimally and can become the main instrument of the government in addition to the state budget to overcome poverty and prosper the people. Based on the facts above, the study aims to look at the role and application of Fintech in collecting ZIS to reduce poverty.

\section{REVIEW OF LITERATURE}

\section{Financial Technology (Fintech)}

Fintech comes from the term Fintech comes from the term financial technology or financial technology. According to The National Digital Research Center (NDRC), in Dublin, Ireland, defines fintech as "innovation financial services" or "innovation in fintech financial services" which is an innovation in the financial sector that gets a touch of modern technology. Financial transactions through this fintech include payments, investments, lending money, transfers, financial plans and comparisons of financial products (Rizal et al., 2019; Santi et al., 2017; Zein, 2019).

Financial Stability Board (FSB) defines Fintech as a digital technology innovation for financial services to produce processes or products related to the provision of financial services (Dudley, 2017; Ginantra et.al., 2020). In a broader sense, Fintech is defined as an industry consisting of companies that use technology to make the financial system and distribution of financial services more efficient (Laksana \& Harja, 2020; Muzdalifa et.al., 2018).

Based on OJK data, Fintech companies in Indonesia consist of: financial planning, lending, crowdfunding, aggregators, payments, and others. Fintech companies in Indonesia are basically dominated by the payment sector $42.22 \%$, the loan sector $17.78 \%$, the aggregator sector $12.59 \%$, the financial planning sector $8.15 \%$, the crowdfunding sector $8.15 \%$, and other fintech sectors $11,11 \%$ (Ginantra et al., 2020; Isabela \& Umam, 2020; Nafiah \& Faih, 2019) . 
Fintech is a modern service solution that can provide satisfaction and convenience to philanthropic funders (Zakāh, Infaq and alms). These innovations can be carried out by fund management institutions through the launch of fintech products for philanthropic purposes. Through this innovation, lenders can channel funds easily. In addition, funders can also know the performance of the managing institution, and it will also increase their trust and satisfaction with the institution (Fahlefi, 2019; Isabela \& Umam, 2020; Yudha et.al., 2021).

In the context of zakāh management, the combination of the zakāh collection system and fintech finally gave birth to an innovation called online zakāh. Online zakāh is a process of paying zakāh carried out through the help of a digital or online system, where the muzakki does not need to meet directly with the zakāh amil in making the payment (Nujaman, 2020).

The form of online zakāh can be in the form of an application or web provided by OPZ to make it easier for muzakki to pay their zakāh anywhere and anytime through the help of electronic communication tools (mobile phones, netbooks, laptops, and so forth) as well as internet connections. This zakāh innovation is chosen by the community because it provides various conveniences. The facilities are; making it easier for muzakki to pay their zakāh without having to go directly to the $\mathrm{OPZ}$ office, the transaction process is easier and faster, economical (zakāh is more efficient online than zakāh directly), and it is easier to reach by everyone.

National Zakāh Strategic Plan (2020) states that the development of a national zakāh system must utilize information technology as an instrument to increase the effectiveness and efficiency of zakāh management services. The accumulation of zakāh, infaq, and alms funds continues to increase and has great potential, so one way that can be used in an effort to maximize its potential is to utilize fintech for the payment aspect (Rachman \& Salam, 2018). Improved fintech features have improved zakāh management in Indonesia. The development of features in the digital world has provided an easy mechanism for the integration and management of zakāh.

\section{Zakāh Management}

The term management comes from the word manage which means to control or organize (Rahum, 2015). Zakāh management means an institution that is specifically tasked 
with administering and managing zakäh. Meanwhile, management means the process of carrying out certain activities by mobilizing the energy of other people, or it can also be interpreted as the process of providing supervision on all matters involved in implementing policies and achieving goals (Havizah et al., 2018). If management is carried out effectively, it will run in a more directed and orderly manner. In relation to zakāh, the process includes collection, distribution, utilization and supervision.

In the management of zakāh, there are several principles that must be followed and adhered to so that the management can be successful in accordance with what is expected, namely the principles of openness, voluntary, integration, professionalism and independence (Djazuli \& Janwari, 2002; Nasrullah et.al., 2020; Yudhira, 2020). Management of zakāh effectively and efficiently, needs to be managed properly. Therefore, zakāh management requires the application of management functions which include planning, organizing, actuating, and controlling. These four things need to be applied in the stages of zakāh management (Hadi, 2020).

\section{Definition and Indicators of Poverty}

Poverty is a condition of limited ability to meet the needs of a decent life such as limitations in income, skills, health conditions, mastery of economic assets, or access to information (Isdijoso \& Suryahadi, 2016). In other sense, poverty is defined as the inability to meet the minimum standard of living where poverty is associated with the absolute standard of living of certain sections of society. In other words, poverty is viewed from at least two sides, namely: absolute poverty and relative poverty (Kuncoro, 2000; Susanto et.al., 2019).

In determining the group of poor people, the minimum standard for measuring poverty is based on the living conditions of a country at a certain time focusing on the "poorest" population group, for example the lowest 20 percent or 40 percent of the total population, which has been sorted by income/expenditure. This group is defined as the relatively poor group. Thus, the relative poverty measure is highly dependent on the condition of the income/expenditure distribution of the population (Kuncoro, 2000).

Poverty is often conceptualized in an economic context, namely the inadequacy of income and assets to meet various basic needs such as food, clothing, housing, education, and health. But actually the definition of poverty is much broader than just a decline in 
income and assets, as the World Bank defines: "Poverty is hunger, lack of shelter, being sick and not being able to go to school and not knowing to know how to read, not having job, fear for the future, living one day at a time, losing a child to illness bring about by unclean water, powerlessness, and lack of representation and freedom" (Kuncoro, 2000).

Foster in Tambunan (1996) mentions three indicators that were introduced to measure poverty, namely: First:The incidence of poverty namely the percentage of the population living in families with per capita consumption expenditures below the poverty line; Second: The depth of poverty which describes the depth of poverty in an area as measured by the Poverty Distance Index (IJK), otherwise known as the Poverty Gap Index. Third: The severity of poverty as measured by the Poverty Severity Index (IKK). This index is in principle the same as the CPI. However, apart from measuring the distance that separates the poor from the poverty line, the IKK also measures inequality among the poor or the distribution of spending among the poor (Mulia \& Saputra, 2020; Purnama, 2017).

\section{RESEARCH METHOD}

The study is a field research based on data obtained from a literature review and based on data from various studies that have been conducted previously. It is quantitative descriptive by describing data and facts related to zakāh management using fintech. The population in this study is the management of ZIS funds by all Zakāh Management Organizations (OPZ) in Indonesia before and after the use of fintech. The study uses a nonprobability sampling technique by purposive sampling and snowball sampling. The purposive sampling used in this study is zakāh management data after the implementation of fintech, namely from 2015 to 2019.

Collecting data in this study, the authors used the method of observation, interviews, and documentation. It also uses secondary data, namely through BAZNAS financial reports and national zakāh statistics for National BAZNAS, as well as other sources relevant to the research. Qualitative data analysis is carried out interactively and takes place continuously until it is complete, so that the data is saturated. The activities in data analysis are: data reduction, data display, and conclusion (Mardalis, 2004). After the data was obtained, the researchers presented the data in the form of brief descriptions, 
charts, relationships between categories, flowcharts and the like. The analysis was carried out based on the reduced data and the results of the analysis were drawn into conclusion.

\section{RESULTS AND DISCUSSION}

\section{Role and Application of Fintech in Zakāh Collection}

In the 2016-2020 National Zakāh Strategic Plan compiled by BAZNAS, it is stated that the development of a national zakāh system must utilize information technology as an instrument to increase the effectiveness and efficiency of zakāh management services (Baznas Strategic Plan Drafting Team, 2016). The accumulation of zakāh, infaq, and alms funds continues to increase and has great potential, so one way that can be used in an effort to maximize its potential is to utilize fintech for the payment aspect (Rachman \& Salam, 2018). Improved fintech features have improved zakāh management in Indonesia. The development of features in the digital world has provided an easy mechanism for the integration and management of zakāh. The 2016-2020 National Zakāh Strategic Plan also mandates that the integration of zakāh management is carried out by utilizing information technology that can be accessed easily, quickly, and efficiently.

National Zakāh Amil Agency makes efforts to collect zakāh, infaq, alms and other religious social funds (DSKL) from domestic and foreign communities through various methods permitted by Sharia. In collecting zakāh, BAZNAS uses several fintech platforms, namely; banking channels, providers of financial technology applications, providers of zakāh hub applications, organizers of crowdfunding applications, providers of e-commerce applications, providers of payment gateways and organizers of social media applications. Besides that, BAZNAS is currently focusing on developing artificial intelligence (AI) based zakāh service technology.

The existence of fintech makes BAZNAS more accessible to muzakki. They can easily pay their zakāh; the limitations of space and time are no longer an obstacle. With fintech, muzakki can pay/pay zakāh anytime and anywhere. Thus, the collection of zakāh also increases. It can be seen by the increasing collection of zakāh nationally in the central BAZNAS report in the table below: 


\section{Table 1}

\section{Collection of ZIS BAZNAS 2015 - 2019}

\begin{tabular}{|l|c|c|c|c|c|}
\hline \multirow{2}{*}{ Institution } & \multicolumn{5}{|c|}{ Collection (Rp) } \\
\cline { 2 - 6 } & $\mathbf{2 0 1 5}$ & $\mathbf{2 0 1 6}$ & $\mathbf{2 0 1 7}$ & $\mathbf{2 0 1 8}$ & $\mathbf{2 0 1 9}$ \\
\hline BAZNAS & $94,068,893,820$ & $111,690,914,428$ & $153,542,103,405$ & $202,187,169,720$ & $296,234,308,349$ \\
\hline B. Province & $642,797,514,841$ & $192,609,000,494$ & $448,171,189,258$ & $552,209,167,922$ & $583,919,722,674$ \\
\hline $\begin{array}{l}\text { B. } \\
\text { District/City }\end{array}$ & $885,309,169,850$ & $3,311,745,042,024$ & $3,426,689,437,619$ & $3,171,701,720,388$ & $3,539,9480,546,674$ \\
\hline LAZ & $2,028,193,434,453$ & $1,401,248,170,005$ & $2,195,968,539,189$ & $3,634,332,619,382$ & $3,728,943,985,109$ \\
\hline $\begin{array}{l}\text { OPZ } \\
\text { Coaching }\end{array}$ & - & - & - & $552,980,000,000$ & $2,078,865,243,749$ \\
\hline \multicolumn{1}{|c|}{ Total } & $\mathbf{3 , 6 5 0 , 3 6 9 , 0 1 2 , 9 6 4}$ & $\mathbf{5 , 0 1 7 , 2 9 3 , 1 2 6 , 9 5 0}$ & $\mathbf{6 , 2 2 4 , 3 7 1 , 2 6 9 , 4 7 1}$ & $\mathbf{8 , 1 1 3 , 4 1 0 , 6 7 7 , 4 1 2}$ & $\mathbf{1 0 , 2 2 7 , 9 4 3 , 8 0 6 , 5 5 5}$ \\
\hline
\end{tabular}

Source: BAZNAS PID Financial Report 2019 (Data processed: 2020)

Table 2

Growth in BAZNAS ZIS Collection 2015 - 2019

\begin{tabular}{|c|c|c|c|}
\hline Year & $\begin{array}{c}\text { ZIS } \\
\text { (Billion Rp) }\end{array}$ & $\begin{array}{c}\text { Growth } \\
(\mathbf{\%})\end{array}$ & $\begin{array}{c}\text { GDP growth } \\
(\mathbf{\%})\end{array}$ \\
\hline 2015 & $3,650.00$ & 10.61 & 5.04 \\
\hline 2016 & $5,017.29$ & 37.46 & 5.02 \\
\hline 2017 & $6,224.37$ & 24.06 & 5.07 \\
\hline 2018 & $8,113.41$ & 30.42 & 5.17 \\
\hline 2019 & $10,227.94$ & 26.00 & 5.02 \\
\hline \multicolumn{2}{|r|}{ Average } & $\mathbf{2 5 . 7 1}$ & $\mathbf{5 . 0 6}$ \\
\hline
\end{tabular}

Source: BAZNAS PID Financial Report 2019 (Data processed: 2020)

The table above illustrates that zakāh receipts from 2015 to 2019 nationally experienced growth with an average growth percentage of $25.71 \%$. The implementation of fintech in $z a k \bar{a} h$ collection by BAZNAS itself began in 2015 where it is evidenced by the significant growth in zakāh collection. The collection of zakāh which was initially only Rp. 3.6 trillion in 2015 can reach Rp. 10.2 trillion at the end of 2019. In 2019 BAZNAS published the portion of zakāh collection based on payment channels and payment platforms which can be seen in the table below; 


\section{Table 3 \\ Collection of ZIS BAZNAS Head Office Based on Payment Channels in 2018}

\begin{tabular}{|l|c|c|}
\hline \multirow{2}{*}{ Via Payment } & \multicolumn{2}{|c|}{ ZIS Collection } \\
\cline { 2 - 3 } & Total Funds (Rp) & $\mathbf{\%}$ \\
\hline \multicolumn{1}{|c|}{$\mathbf{2}$} & $\mathbf{3}$ \\
\hline Counter & $12,696,795,048$ & 6.15 \\
E-Payment & $32,204,405,895$ & 15.60 \\
Transfer & $161,472,974,632$ & 78.24 \\
\hline \multicolumn{1}{|c|}{ Total } & $\mathbf{2 0 6 , 3 7 4 , 1 7 5 , 5 7 5}$ & $\mathbf{1 0 0 . 0 0}$ \\
\hline \multicolumn{2}{|c|}{ Source: National Zakăh Statistics (2018) }
\end{tabular}

Table 4

Collection of ZIS BAZNAS Head Office By 2019 Payment Channel

\begin{tabular}{|l|r|c|}
\hline \multirow{2}{*}{$\begin{array}{c}\text { Payment } \\
\text { Channel }\end{array}$} & \multicolumn{2}{|c|}{ ZIS Collection } \\
\cline { 2 - 3 } & Total Funds (Rp) & $\mathbf{\%}$ \\
\hline \multicolumn{1}{|c|}{$\mathbf{2}$} & $\mathbf{3}$ \\
\hline Counter & $7,798,664,544$ & 2.6 \\
E-Payment & $40,183,311,927$ & 13.6 \\
Transfer & $238,992,463,834$ & 80.7 \\
Nature & $9,259,868.044$ & 3.1 \\
\hline \multicolumn{1}{|c|}{ Total } & $\mathbf{2 9 6 , 2 3 4 , 3 0 8 , 3 4 9}$ & $\mathbf{1 0 0 . 0 0}$ \\
\hline
\end{tabular}

Source: National Zakāh Statistics (2018)

The table above illustrates the portion of zakāh collection in 2018 using the transfer method of $78.2 \%$ and in 2019 it increased to 80.7\%, the E-Payment method 15.6\% in 2018 decreased to $13.6 \%$ in 2019. Then, in 2018 manual payments through the counter amounted to $6.15 \%$ and in 2019 it fell to $2.6 \%$. Therefore, it can be concluded that the majority of muzakki pay zakāh online using transfer and e-payment method. It proves that the contribution of payments through fintech is very dominant compared to manual payment counters.

Zakāh collection, BAZNAS Prov. DIY also collaborates with crowdfunding platform partners such as kitabisa.com_for the convenience of zakāh services for muzakki. Another innovation that has been made by BAZNAS is the voice-command zakāh service called Lena and can be downloaded on smartphone applications, one of which is the 
Playstore. The following are the achievements of the DIY BAZNAS zakāh collection in the last 5 years.

Table 5

\section{Collection of ZIS BAZNAS Prov. DIY 2015-2019}

\begin{tabular}{|c|c|c|c|c|c|c|}
\hline No. & Data Type & 2019 & 2018 & 2017 & 2016 & 2015 \\
\hline 1. & Zakāh & $3,568,638,141$ & $2,756,961,728$ & $1,673,912,537$ & $1,557,107,353$ & $680,990,478$ \\
\hline 2. & Zakāh Fitrah & $446,164,957$ & $5,360,000$ & 410,000 & $3,705,000$ & - \\
\hline 3. & $\begin{array}{l}\text { Infaq/Unbound Alms } \\
\text { (ISTT) }\end{array}$ & $464,512,452$ & $297,889,923$ & $260,882,634$ & $165,646,546$ & $238,019,423$ \\
\hline 4. & $\begin{array}{lll}\begin{array}{l}\text { Infaq/ } \\
\text { (IST) }\end{array} & \text { Tied } & \text { Alms } \\
\end{array}$ & $124,915,013$ & - & - & - & - \\
\hline 5. & $\begin{array}{l}\text { Corporate } \quad \text { Social } \\
\text { Responsibility (CSR) }\end{array}$ & - & $5,000,000$ & $15,000,000$ & $5,000,000$ & - \\
\hline 6. & $\begin{array}{l}\text { Other Religious } \\
\text { Social Funds (DSKL) }\end{array}$ & $109,864,247$ & $163,747,100$ & $205,558,100$ & - & - \\
\hline \multicolumn{2}{|r|}{ Total ZIS and DSKL } & $4,714,094,810$ & $3,228,958,751$ & $2,155,763,271$ & $1,731,458,899$ & $919,009,901$ \\
\hline
\end{tabular}

Source: Annual Report of BAZNAS Prov. DIY (2019)

Table 5 above describes the portion of zakāh collection of BAZNAS Prov. DIY from 2015 to 2019 has increased. This is influenced by the application of the use of EPayment in paying zakāh, where this data shows an increase in zakāh receipts at BAZNAS Prov. DIY is in line with the increase in zakāh collection nationally in 2019.

Although there has been an increase in terms of collection, this increase is still far from the potential of Indonesian zakāh which reaches IDR $217 \mathrm{~T}$ or $3-4 \%$ of the existing potential. It indicates that despite using technology in collecting zakāh and providing convenience for muzakki to pay zakāh, there are still various obstacles faced by Zakāh Management Organizations (OPZ) throughout Indonesia to achieve this large zakāh potential. According to the chairman of BAZNAS, there are various obstacles in collecting zakāh, namely: Zakāh collection has not been integrated in one institution; Not all people, especially muzakki, understand technology; Public trust in OPZ is still low; and not all OPZs implement the BAZNAS Information System (SiMBA), although Central BAZNAS already has the app.

The BAZNAS Information System (SiMBA) is an application-based zakāh entry system that is used for the $z a k \bar{a} h$ recording and reporting process with the aim that $z a k \bar{a} h$ collection is integrated nationally, professionally and transparently. The following are the number of active SIMBA users in 2018 and 2019; 
Table 6

Number of Active Users SIMBA 2018

\begin{tabular}{|cccc|}
\hline \multirow{2}{*}{$\begin{array}{c}\text { Zakīh } \text { Management } \\
\text { Level of OPZ }\end{array}$} & $\begin{array}{c}\text { Amount } \\
\text { Total }\end{array}$ & \multicolumn{2}{c|}{$\begin{array}{c}\text { SiMBA Active User } \\
\text { Active Users SiMBA }\end{array}$} \\
\cline { 3 - 4 } & & $\begin{array}{c}\text { Amount } \\
\text { Total }\end{array}$ & \% \\
\hline 1 & $\mathbf{2}$ & $\mathbf{3}$ & $\mathbf{4}$ \\
\hline Provincial BAZNAS & 34 & 21 & 12.28 \\
District/City BAZNAS & 514 & 148 & 86.55 \\
LAZ & 68 & 2 & 1.17 \\
\hline & $\mathbf{6 1 6}$ & $\mathbf{1 7 1}$ & $\mathbf{1 0 0 . 0}$ \\
\hline
\end{tabular}

Table 6 above illustrates that in 2018 only 171 OPZ and 21 Provincial BAZNAS out of a total of $616 \mathrm{OPZ}$ and 34 Provinces were active users of SiMBA. The list of active users of SIMBA in 2019, namely:

Table 7

Number of active users of SIMBA 2019

\begin{tabular}{|c|c|c|c|}
\hline \multirow{2}{*}{$\begin{array}{c}\text { OPZ tiers } \\
\text { Level of OPZ }\end{array}$} & \multirow{2}{*}{$\begin{array}{c}\text { Amount } \\
\text { Total }\end{array}$} & \multicolumn{2}{|c|}{$\begin{array}{l}\text { SiMBA Active User } \\
\text { Active Users SiMBA }\end{array}$} \\
\hline & & $\begin{array}{c}\text { Amount } \\
\text { Total }\end{array}$ & $\%$ \\
\hline 1 & 2 & 3 & 4 \\
\hline Provincial BAZNAS & 34 & 20 & 11.4 \\
\hline District/City BAZNAS & 514 & 151 & 85.8 \\
\hline LAZ & 79 & 5 & 2.8 \\
\hline Total & 627 & 176 & 100.0 \\
\hline
\end{tabular}

Source: National Zakāh Statistics 2019

The comparison of SIMBA active users in 2018 and 2019 are:

Table 8

Comparison of Active Users in 2018-2019

\begin{tabular}{|c|c|c|c|c|}
\hline \multirow[b]{2}{*}{$\begin{array}{c}\text { OPZ tiers } \\
\text { Level of OPZ }\end{array}$} & \multicolumn{2}{|c|}{2018} & \multicolumn{2}{|c|}{2019} \\
\hline & $\begin{array}{c}\text { Amount } \\
\text { Total }\end{array}$ & $\%$ & $\begin{array}{c}\text { Amount } \\
\text { Total }\end{array}$ & $\%$ \\
\hline 1 & 2 & 3 & 4 & 5 \\
\hline Provincial BAZNAS & 21 & 12.3 & 20 & 11.4 \\
\hline District/City BAZNAS & 148 & 96.5 & 151 & 85.8 \\
\hline LAZ & 2 & 1.2 & 5 & 2.8 \\
\hline Total & 171 & 100.0 & 176 & 100.0 \\
\hline
\end{tabular}

Source: National Zakāh Statistics 2018 and 2019 
Table 8 above describes SIMBA's active users in 2018 only around $171 \mathrm{OPZ}$ then in 2019 it rose to 176 OPZ. However, the number of OPZ active users of SIMBA is still quite small when compared to a total of $627 \mathrm{OPZ}$ throughout Indonesia. Thus, it can be assumed that the data regarding the reporting and collection of zakāh nationally has not been well integrated and there may be "missing" in the reporting of zakāh. However, BAZNAS continues to hold socialization and training on the use of SiMBA which is attended by all representatives of provincial BAZNAS operators and LAZ so that it is expected that all zakāh management institutions in Indonesia will be integrated through this application and data regarding zakāh collection will become more accurate, accountable, professional and transparent.

Currently, BAZNAS is also continuing to innovate in developing multi-platform digital fundraising which later gave birth to 41 digital channels, including through online stores, financial technology, virtual zakāh game assistants and the latest is Augmented Reality. BAZNAS will continue to innovate both in the receipt and distribution of zakāh, especially by utilizing technological developments. BAZNAS will encourage the zakāh collection program so that the collection continues to increase so that there are more programs that are beneficial for mustahiq.

\section{The Role of Fintech in Zakāh Management to Relieve Poverty}

Fintech is a means used to make it easier for muzakki to pay their zakāh to BAZNAS. All zakāh funds collected both offline and online (fintech) are recorded as BAZNAS collection if the funds have been validated that the funds have actually entered the BAZNAS account.

The collection of zakāh using Fin-Tech which continues to increase has a direct impact on the distribution of zakāh from 2015 to 2019. This can be seen in the table below:

Table 9

Growth and Distribution Portion of ZIS Based on the 2015-2016 Zakāh Management Organization

\begin{tabular}{|c|c|c|c|c|c|c|}
\hline \multirow{2}{*}{ Institution } & \multicolumn{2}{|c|}{2015 Distribution } & \multicolumn{2}{|c|}{2016 Distribution } & \multicolumn{2}{|l|}{ Growth } \\
\hline & Total Funds (Rp) & $\%$ & Total Funds (Rp) & $\%$ & Total Funds (Rp) & $\%$ \\
\hline 1 & 2 & 3 & 4 & 5 & 6 & 7 \\
\hline BAZNAS & $66,766.033,369$ & 2.97 & $80,252,586.454$ & 2.74 & $13,486,553,085$ & 20.20 \\
\hline $\begin{array}{l}\text { Provincial } \\
\text { BAZNAS }\end{array}$ & \multirow{2}{*}{$920,263,800,525$} & \multirow{2}{*}{40.92} & $108,379,364,672$ & 3.70 & \multirow{2}{*}{$766,832,700,117$} & \multirow{2}{*}{83.33} \\
\hline $\begin{array}{l}\text { District/City } \\
\text { BAZNAS }\end{array}$ & & & $1,578,717,135,970$ & 53.86 & & \\
\hline
\end{tabular}




\begin{tabular}{|c|c|c|c|c|c|c|}
\hline LAZ & $1,262,130,957,632$ & 56.12 & $1,163,861,023,514$ & 39.71 & $-98,269,934,118$ & -7.79 \\
\hline Total & $2,249,160,791,526$ & 100.00 & $2,931,210,110,610$ & 100.00 & $682,049,319,084$ & 30.32 \\
\hline
\end{tabular}

Source: National Zakāh Statistics (2016)

\section{Table 10}

\section{Growth and Distribution Portion of ZIS} Based on Zakāh Management Organization 2017-2019

\begin{tabular}{|c|c|c|c|c|c|c|}
\hline \multirow[b]{2}{*}{$\begin{array}{c}\text { OPZ tiers } \\
\text { Level of OPZ }\end{array}$} & \multicolumn{2}{|c|}{$\begin{array}{c}2017 \text { Distribution } \\
\text { Disbursement in } 2017\end{array}$} & \multicolumn{2}{|c|}{$\begin{array}{c}\text { 2018 Distribution } \\
\text { Disbursement in } 2018 \\
\end{array}$} & \multicolumn{2}{|c|}{$\begin{array}{l}\text { 2019 Distribution } \\
\text { Disbursement in } 2019\end{array}$} \\
\hline & $\begin{array}{l}\text { Total Funds (Rp) } \\
\text { Total Amount (Rp) }\end{array}$ & $\%$ & $\begin{array}{l}\text { Total Funds (Rp) } \\
\text { Total Amount (Rp) }\end{array}$ & $\%$ & $\begin{array}{l}\text { Total Funds (Rp) } \\
\text { Total Amount } \\
(\mathrm{Rp})\end{array}$ & $\%$ \\
\hline 1 & 2 & 3 & 4 & 5 & 6 & 7 \\
\hline BAZNAS & $131,917,747,764$ & 2.7 & $235,664,651,030$ & 2.7 & $270,716,950,765$ & 3.1 \\
\hline $\begin{array}{l}\text { Provincial } \\
\text { BAZNAS }\end{array}$ & $388,168,225,347$ & 3.7 & $462,230,919,380$ & 8.0 & $481,796,534,289$ & 5.5 \\
\hline $\begin{array}{l}\text { District/City } \\
\text { BAZNAS }\end{array}$ & $2,629,588,214,952$ & 53.9 & $2,490,478,790,649$ & 54.1 & $2,586,872,888,351$ & 29.8 \\
\hline LAZ & $1,710,481,136,382$ & 39.7 & $3,100,034,381,065$ & 35.2 & $3,519,873,720,039$ & 40.5 \\
\hline $\begin{array}{ll}\text { OPZ } & \text { in } \\
\text { Institutional } & \\
\text { Development } & \end{array}$ & (1) & 0.0 & $511,730,391,073$ & 0.0 & $1,828,961,140,910$ & 21.1 \\
\hline Total & $4,860,155,324,445$ & 100.0 & $6,800,139,133,196$ & 100.0 & $8,688,221,234,354$ & 100.0 \\
\hline
\end{tabular}

Source: National Zakāh Statistics (2019)

Tables 9 and 10 above can be seen that the distribution of zakāh during the last five years has increased. In 2015, the total funds disbursed by BAZNAS amounted to Rp. $2,249,160,791,526$ trillion. Then in 2016, it increased with a total of Rp. 2,931,210,110,610 trillion, 2017 experienced a significant increase of Rp. Rp. 4,860,155,324,445 trillion, then in 2018 the zakāh funds distributed by BAZNAS reached Rp. 6,800,139,133,196 trillion. And in 2019, the zakäh funds distributed reached Rp. 8,688,221,234,354 trillion. The zakāh funds are channeled into various fields, this can be seen in the following table:

Table 11

\section{Distribution Comparison by Sector 2015-2016}

\begin{tabular}{|c|c|c|c|c|c|c|}
\hline \multirow{2}{*}{ Field } & \multicolumn{2}{|c|}{2015 Distribution } & \multicolumn{2}{|c|}{2016 Distribution } & \multicolumn{2}{|l|}{ Growth } \\
\hline & Total Funds (Rp) & $\%$ & Total Funds (Rp) & $\%$ & Total Funds (Rp) & $\%$ \\
\hline 1 & 2 & 3 & 4 & 5 & 6 & 7 \\
\hline Economy & $315,127,234,587$ & 15.11 & $493,075,489,398$ & 18.30 & $177,948,254,811$ & 56.47 \\
\hline Education & $432,068,068,508$ & 20.72 & $842,980,341,134$ & 31.28 & $410,912,272,628$ & 95.10 \\
\hline Da'wah & $303,553,206,946$ & 14.56 & $418,454,281,897$ & 15.53 & $114,901,074,951$ & 37.85 \\
\hline Health & $188,685,220,166$ & 9.05 & $228,004,399,823$ & 8.39 & $37,319,179,657$ & 19.78 \\
\hline Humane Social & $846,038,250,681$ & 40.57 & $714,267,956,361$ & 26.51 & $-131,770,294,320$ & $\begin{array}{r}- \\
15.75\end{array}$ \\
\hline Total & $2,085,471,980,888$ & 100.0 & $2,694,782,468,613$ & 100.0 & $609,310,487,725$ & 29.22 \\
\hline
\end{tabular}

Source: National Zakāh Statistics (2016)

\begin{tabular}{ll|l} 
The Role of Financial Technology ..... & 215
\end{tabular} 
Table 12

Distribution Comparison by Sector 2017- 2018

\begin{tabular}{|c|c|c|c|c|c|c|}
\hline \multirow[b]{2}{*}{ Field } & \multicolumn{2}{|c|}{2017 Distribution } & \multicolumn{2}{|c|}{2018 Distribution } & \multicolumn{2}{|l|}{ Growth } \\
\hline & Total Funds (Rp) & $\%$ & Total Funds (Rp) & $\%$ & $\begin{array}{l}\text { Total Funds } \\
\text { (Rp) }\end{array}$ & $\%$ \\
\hline 1 & 2 & 3 & 4 & 5 & 6 & 7 \\
\hline Economy & $882,515,274,729$ & 2033 & $552,166,541,845$ & 10.06 & $330,348,732,884$ & $\begin{array}{c}- \\
37.43\end{array}$ \\
\hline Education & $941,865,099,137$ & 21.69 & $1,438,512,064,225$ & 26.20 & $496,646,965,087$ & 52.73 \\
\hline Da'wah & $979,468,717,694$ & 22.56 & $1,288,101,574,916$ & 23.46 & $308,632,857,222$ & 31.51 \\
\hline Health & $413,507,938,849$ & 9.52 & $462,616,244,461$ & 8.43 & $49,108,305,612$ & 11.88 \\
\hline Humane Social & $1,124,150,826,782$ & 25.89 & $1,749,044,945,469$ & 31.86 & $624,894,118,687$ & 55.59 \\
\hline Total & $4,341,507,857,190$ & 100.0 & $5,490,441,370,915$ & 100.0 & $\begin{array}{r}1,148,933,513,7 \\
25\end{array}$ & 26.46 \\
\hline
\end{tabular}

Source: National Zakāh Statistics (2018)

Table 13

Distribution Comparison by Sector 2018-2019

\begin{tabular}{|l|r|c|c|c|c|c|}
\hline \multirow{2}{*}{ Field } & \multicolumn{2}{|c|}{ 2018 Distribution } & \multicolumn{2}{c|}{ 2019 Distribution } & \multicolumn{2}{c|}{ Growth } \\
\cline { 2 - 7 } & Total Funds (Rp) & $\mathbf{\%}$ & Total Funds (Rp) & $\mathbf{\%}$ & Total Funds (Rp) & \% \\
\hline \multicolumn{1}{|c|}{$\mathbf{2}$} & $\mathbf{3}$ & $\mathbf{4}$ & $\mathbf{5}$ & $\mathbf{6}$ & $\mathbf{7}$ \\
\hline Economy & $552,166,541,845$ & 10.06 & $841,159,855,062$ & 13.5 & $288,993,313,217$ & 52.3 \\
\hline Education & $1,438,512,064,225$ & 26.20 & $1,201,622,002,187$ & 19.3 & $-236,890,062,038$ & -16.5 \\
\hline Da'wah & $1,288,101,574,916$ & 23.46 & $1,553,693,450,575$ & 25.0 & $265,591,875,659$ & 20.6 \\
\hline Health & $462,616,244,461$ & 8.43 & $325,291,528,224$ & 5.2 & $-137,324,716,237$ & -29.7 \\
\hline Humane Social & $1,749,044,945,469$ & 31.86 & $2,296,711,735,408$ & 36.9 & $547,666,789,940$ & 31.3 \\
\hline \multicolumn{1}{|c|}{ Total } & $\mathbf{5 , 4 9 0 , 4 4 1 , 3 7 0 , 9 1 5}$ & $\mathbf{1 0 0 . 0}$ & $\mathbf{6 , 2 1 8 , 4 7 8 , 5 7 1 , 4 5 5}$ & $\mathbf{1 0 0 . 0}$ & $\mathbf{7 2 8 , 0 3 7 , 2 0 0 , 5 4 0}$ & $\mathbf{1 3 . 3}$ \\
\hline
\end{tabular}

Source: National Zakāh Statistics (2019)

The table above illustrates that zakāh funds distributed from 2015 to 2019 are more dominated in the social and humanitarian fields. Zakāh funds distributed in the social and humanitarian sector in 2019 reached Rp. 2.2 trillion or approximately (36.9\%) of the total disbursed funds. Subsequently distributed in the field of da'wah with the amount of Rp. 1.5 trillion (25\%), education with a total of Rp. 1.2 trillion (19.3\%), and health with a total of 325 billion (5.2\%). Meanwhile, zakāh distribution in the form of utilization in 2019 was in the economic sector of Rp. 841 billion (13.5\%).

These data indicate that the distribution of zakāh is greater in terms of distribution than utilization to mustahiq, where the distribution of zakāh in the form of distribution is given in various forms of assistance, namely; provision in the form of health assistance, educational assistance, socialization assistance, disaster assistance, da'wah assistance and converts, etc., while distribution is for economic empowerment of mustahiq in the form of 
fostered skills training, formation of SMEs, production cultivation, facilitating production equipment such as agriculture, animal husbandry, and industry as well as providing capital.

BAZNAS gave birth to 349 Z-Mart Stalls, 6 units of BAZNAS Microfinance Village (BMD) financial institutions, 4 Food Barns, 18 Livestock Centers and 103 Community Development Zakāh points (ZCD). A number of BAZNAS in the regions now have BAZNAS Active Services (LAB) and Disaster Response BAZNAS (BTB) which are ready to help people in need.

The distribution of zakāh is closely monitored by a special work unit, namely the Directorate of Compliance and Internal Audit (DKAI). DKAI is a kind of internal auditor who ensures that the distribution is on the track. And there is sharia supervision or audit from the Ministry of Religion, to ensure the distribution does not violate Islamic sharia. In terms of distribution, BAZNAS applies fintech through a payment gateway to mustahiq. However, the application of using the Payment Gateway is considered ineffective because some mustahiq do not have the application and do not understand the use of fintech. There are two types of zakāh distribution, namely distribution and utilization. Through this utilization mechanism, BAZNAS plays a role in building a work ethic, business spirit, and empowerment assistance to improve the quality of life and independence of mustahiq. Utilization is intended as an arena for BAZNAS in alleviating/overcoming poverty.

BAZNAS Prov. DIY also has a productive zakāh program that aims to improve the community's economy, namely Yogya Sejahtera which has undergone changes in its program. Since 2017 BAZNAS Prov. DIY has the "Mas Zakky Group" program, which is a business unit consisting of three programs. First, "Mas Zakky Angkringan" is a program of training, mentoring and providing capital to mustahiq for the angkringan business. Second, "Mas Zakky Gorengan" is a training program in business which is then given to mustahiq in the form of a cart for business. The third "Mas Zakky Cell" is the provision of capital for mustahiq in the credit business. BAZNAS Prov. DIY does not only provide capital, but also provides training to become a good and true entrepreneur through the "School of Merchant" program.

Then there are various productive $z a k \bar{a} h$ programs in other economic fields, namely "Senyum Mandiri" in this program there are three types of activities. First, SME Empowerment, an economic empowerment program based on small and micro businesses. 
Second, the productive agriculture program which is an empowerment program to encourage young farmers through the assistance of production facilities, agricultural machinery, superior seeds and mentoring. Third, the productive livestock program is to help farmers have additional income from livestock, through the assistance of superior seeds and production facilities. The following are the zakāh funds distributed to mustahiq in 2015-2019, namely:

Table 14

Growth and Distribution of ZIS BAZNAS Prov. DIY 2015 - 2019

\begin{tabular}{|c|l|c|c|c|c|c|}
\hline No. & \multicolumn{1}{|c|}{ Data Type } & $\mathbf{2 0 1 9}$ & $\mathbf{2 0 1 8}$ & $\mathbf{2 0 1 7}$ & $\mathbf{2 0 1 6}$ & $\mathbf{2 0 1 5}$ \\
\hline 1. & Zakāh for the Poor & $35,181,509$ & $450,325,882$ & $1,568,532,666$ & $580,611,000$ & $76,575,000$ \\
\hline 2. & Zakāh for the Poor & $2,862,610,982$ & $1,996,997,253$ & - & - & $313,070,000$ \\
\hline 3. & Zakāh for Amil & $407,425,990$ & 174.952 .117 & $253,216,857$ & $119,057,874$ & $97,559,200$ \\
\hline 4. & Zakāh for Muallaf & $2,000,000$ & $24,890,000$ & $2,800,000$ & $4,480,000$ & $1,000,000$ \\
\hline 5. & Zakāh for Riqab & - & - & - & - & - \\
\hline 6. & Zakāh for Gharimin & $1,000,000$ & 200,000 & - & - & - \\
\hline 7. & Zakāh for Sabillah & $491,804,945$ & $394,456,080$ & $297,914,825$ & $188,724,150$ & - \\
\hline 8. & Zakāh for Ibn Sabil & 2.050 .000 & 1.060 .000 & 605,000 & $8,951,000$ & $7,475,000$ \\
\hline 9. & $\begin{array}{l}\text { ISTT for Mustahiq } \\
\text { (Non-Amil) }\end{array}$ & $547,852,610$ & $338,174,426$ & $229,836,664$ & $182,696,878$ & $287,484,000$ \\
\hline 10. & ISTT for Amil & $92,882,488$ & $25,704,694$ & $30,906,818$ & - & - \\
\hline 11. & $\begin{array}{l}\text { IST for Mustahiq } \\
\text { (Non-Amil) }\end{array}$ & - & - & - & - & - \\
\hline 12. & IST for Amil & - & - & - & - & - \\
\hline 13. & $\begin{array}{l}\text { Corporate Social } \\
\text { Responsibility (CSR) }\end{array}$ & - & $5,000,000$ & - & - & - \\
\hline 14. & $\begin{array}{l}\text { CSR Distribution } \\
\text { Operations }\end{array}$ & - & - & - & - & - \\
\hline 15. & $\begin{array}{l}\text { Other Religious } \\
\text { Social Funds (DSKL) }\end{array}$ & $122,799,600$ & $114,363,100$ & 205.558 .100 & - & - \\
\hline 16. & $\begin{array}{l}\text { DSKL Distribution } \\
\text { Operations }\end{array}$ & - & - & - & - & - \\
\hline
\end{tabular}

Table 15

Distribution Comparison by Sector BAZNAS Prov. DIY 2015- 2019

\begin{tabular}{|c|l|r|r|r|r|r|}
\hline No. & \multicolumn{1}{|c|}{ Data Type } & $\mathbf{2 0 1 9}$ & $\mathbf{2 0 1 8}$ & \multicolumn{1}{c|}{$\mathbf{2 0 1 7}$} & $\mathbf{2 0 1 6}$ & \multicolumn{1}{c|}{$\mathbf{2 0 1 5}$} \\
\hline 1. & Economics & $183,048,000$ & 443.530 .960 & $137,500,000$ & 187.500 .000 & $271,575,000$ \\
\hline 2. & $\begin{array}{l}\text { Field of } \\
\text { education }\end{array}$ & $2,203,448,007$ & $1,668,514,351$ & $1,367,755,761$ & $316,231,000$ & $52,080,000$ \\
\hline 3. & Health & $144,073,548$ & $186,547,984$ & $24,737,790$ & $4,280,000$ & $7,900,000$ \\
\hline 4. & Humanity Field & $783,058,182$ & $372,976,500$ & $196,769,870$ & $137,716,000$ & $20,485,000$ \\
\hline 5. & $\begin{array}{l}\text { Field of Da'wah } \\
\text { - Advocacy }\end{array}$ & 751.671 .909 & $653,896,946$ & $373,025,734$ & $320,136,028$ & $287,484,000$ \\
\hline
\end{tabular}

Source: Annual Report of BAZNAS Prov. DIY (2019) 
Utilization of zakāh funds, or what can be called productive zakāh, is intended so that mustahiq can become independent, have knowledge, and have a sense of responsibility towards the zakāh funds given so that in the future mustahiq do not depend on zakāh and it is hoped that for the next year the mustahiq can get out of poverty and switch status to muzzaki. The following is the number of poor people who are eradicated from the BPS version of the poverty line based on the OPZ;

Table 16

The Poor Eradicated from the Poverty Line BPS Version Based on OPZ 2019

\begin{tabular}{|lcc|}
\hline \multicolumn{1}{|c}{$\begin{array}{c}\text { OPZ tiers } \\
\text { Level of OPZ }\end{array}$} & $\begin{array}{c}\text { Realization } \\
\text { Achievements }\end{array}$ & $\begin{array}{c}\text { Percentage (\%) } \\
\text { Percentage (\%) }\end{array}$ \\
\hline \multicolumn{1}{|c|}{$\mathbf{1}$} & $\mathbf{2}$ & $\mathbf{3}$ \\
\hline BAZNAS & 15,750 & 8.2 \\
Provincial BAZNAS & 9,293 & 4.9 \\
BAZNAS & 71.529 & 37.4 \\
Regency/City & 94.518 & 49.5 \\
LAZ & $\mathbf{1 9 1 , 0 9 0}$ & $\mathbf{1 0 0 . 0}$ \\
\hline \multicolumn{1}{|c|}{ Total } \\
Source: National Zakāh Statistics (2019)
\end{tabular}

Table 16 illustrates that as many as 191,090 poor people have been removed from the poverty line in Indonesia by OPZ. However, this number is still quite small from the total poor population in Indonesia in 2019. According to the Central Statistics Agency (BPS), the number of poor people in March 2019 was 25.14 million people. It means that the ratio of the number of poor people alleviated by OPZ is around $0.76 \%$. But at least based on these data, zakāh distribution by OPZ has contributed to alleviating poverty in Indonesia. This is directly related to the distribution of zakāh by BAZNAS where the distribution of zakāh in the form of economic empowerment and empowerment of mustahiq is still relatively small in number. If all the funds collected are channeled in the form of economic empowerment and empowerment, it will lead to a minimum number of mustahiq who will receive zakäh. Economic empowerment, such as providing capital for mustahiq, requires substantial funds.

The productive zakāh program is not as easy as the distribution of consumptive zakāh. If in the distribution of consumptive zakāh, only direct funds are distributed to 
mustahiq without seeing the effect that will quickly run out or which will only run out to meet the needs of the mustahiq's life. Meanwhile, in the distribution of productive zakāh funds, it is demanded to be able to develop and be sustainable. Then, mustahiq can and fulfill the needs of daily life which later is expected by them to become muzakki. Therefore, in the management of productive zakāh distribution, maximum effort and seriousness are needed in order to achieve an increase in the community's economy and make the right solution in alleviating poverty.

Based on this, it is quite natural that the realization of BAZNAS in alleviating the poverty line is not yet optimal. It is undeniable that the distribution of $z a k \bar{a} h$ in the form of economic empowerment has a significant impact on mustahiq to get out of the poverty line. However, the various obstacles faced by BAZNAS such as the collection of zakāh that has not been optimal and limited human resources in supervising and fostering mustahiq make zakāh not enough to contribute to alleviating poverty in Indonesia.

\section{CONCLUSION}

The collection of zakāh using Fintech which continues to increase has a direct impact on the distribution of zakāh from 2015 to 2019, where the growth of zakāh distribution from 2015 to 2019 has increased quite significantly, reaching an average of $40.93 \%$. The majority of zakāh funds distributed are in the form of distribution rather than utilization. Throughout 2019, the Central Baznas has assisted 755,536 mustahiq. BAZNAS gave birth to 349 Z-Mart Stalls, 6 units of BAZNAS Microfinance Village (BMD) financial institutions, 4 Food Barns, 18 Livestock Centers and 103 Community Development Zakāh points (ZCD). Likewise, BAZNAS Prov. DIY is experiencing an increase, but in 2019 the distribution of zakāh by BAZNAS DIY is more prioritized in the education sector. Based on data obtained by the poor who were eradicated from the poverty line based on OPZ according to BPS, it reached 191,090 people. According to BPS, the number of poor people in Indonesia in March 2019 was 25.14 million people. It means that the ratio of the number of poor people alleviated by OPZ is around $0.76 \%$. It is directly related to the distribution of zakāh by BAZNAS where the distribution of zakāh in the form of economic empowerment and empowerment of mustahiq is still relatively small in number. 


\section{REFERENCES}

Aaron, M., Rivadeneyra, F., \& Sohal, S. (2017). Fintech: Is This Time Different? A Framework for Assessing Risks and Opportunities for Central Banks. Bank of $\begin{array}{lllll}\text { Canada Staff Discussion } & \text { 2017-10, }\end{array}$ https://www.bankofcanada.ca/2017/07/staff-discussion-paper-2017-10/.

Afdali, A. A., Sanusi, N. T., \& Cahyani, A. I. (n.d.). Pengelolaan Zakat Terhadap Pengentasan Kemiskinan Pada Baznas Kabupaten Soppeng. Iqtishaduna: Jurnal Ilmiah Mahasiswa Hukum Ekonomi Syari'ah, 3(2), 21-29. http://journal.uinalauddin.ac.id/index.php/iqtishaduna/article/view/22318.

Atabik, A. (2016). Manajemen Pengelolaan Zakat yang Efektif di Era Kontemporer. ZISWAF: Jurnal Zakat Dan Wakaf, 2(1), 40-62. https://doi.org/10.21043/ziswaf.v2i1.1535.

Baznas. (2021). BAZNAS. https://baznas.go.id/id/channel-pembayaran.

Choirunnisa, I., Ramadhani, A., Febrianty, A., Shifa, L., Rizal, M., \& Nurbayanti, S. (2021). Model Edukasi Keuangan Melalui Literasi Keuangan Digital Syariah di Indonesia. El Ujrah: Journal of Islamic Banking and Finance, 1(1), Article 1. http://www.jurnal.stesislamicvillage.ac.id/index.php/ElUjrah/article/view/148.

Djazuli, \& Janwari, Y. (2002). Lembaga-lembaga Perekonomian Umat. Raja Grafindo Persada.

Dudley, W. C. (2017). FinTech credit: Market structure, business models and financial stability implications. Bank for International Settlements and Financial Stability Board.

Fahlefi, R. (2019). Inklusi Keuangan Syariah Melalui Inovasi Fintech di Sektor Filantropi. Proceeding IAIN Batusangkar, 4(1), 205-212. https://ojs.iainbatusangkar.ac.id/ojs/index.php/proceedings/article/view/1556.

Fitri, M. (2017). Pengelolaan Zakat Produktif sebagai Instrumen Peningkatan Kesejahteraan Umat. Economica: Jurnal Ekonomi Islam, 8(1), 149-173. https://doi.org/10.21580/economica.2017.8.1.1830.

Ginantra, N. L. W. S. R., Simarmata, J., Purba, R. A., \& Tojiri, M. Y. (2020). Teknologi Finansial: Sistem Finansial Berbasis Teknologi di Era Digital. Yayasan Kita Menulis.

Hadi, R. (2020). Manajemen Zakat, Infaq, dan Shadaqah di Badan Amil Zakat Nasional (BAZNAS) Kabupaten Banyumas. el-Jizya : Jurnal Ekonomi Islam, 8(2), 245-266. https://doi.org/10.24090/ej.v8i2.3750.

Havizah, H., Ifansyah, M. N., \& Arbayah, S. (2018). Pengelolaan Dana Desa dalam Pemberdayaan Jalan Usaha Tani di Desa Maburai Kecamatan Murung Pudak Kabupaten Tabalong. $\quad J A P B, \quad 1(1), \quad 137-152$. http://jurnal.stiatabalong.ac.id/index.php/JAPB/article/view/108. 
Isabela, \& Umam, M. (2020). Optimalisasi Fintech di Sektor Filantropi Islam untuk Pengembangan ZISWAF. EKOSIANA: Jurnal Ekonomi Syariah, 7(2), 75-85. http://journal.stainim.ac.id/index.php/ekosiana/article/view/40.

Isdijoso, W., \& Suryahadi, A. (2016). Penetapan Kriteria dan Variabel Pendataan Penduduk Miskin yang Komprehensif dalam Rangka Perlindungan Penduduk Miskin di Kabupaten/Kota. The SMERU Research Institute, 25.

Kuncoro, M. (2000). Ekonomi Pembangunan (Teori, Masalah dan Kebijakan) (Ke-2). YKPN.

Laksana, A. P., \& Harja, R. P. (2020). Perbandingan Regulasi Financial Technology Terkait Perlindungan Data Nasabah Di Indonesia Dengan Negara Lainnya. Rechtidee, 15(2), 293-312. https://doi.org/10.21107/ri.v15i2.5411.

Mardalis. (2004). Metode Penelitian Suatu Pendekatan Proposal (Cet. ke-7). Bumi Aksara.

Mulia, R. A., \& Saputra, N. (2020). Analisis Faktor-Faktor Yang Mempengaruhi Kesejahteraan Masyarakat Kota Padang. EL-RIYASAH, 11(1), 67-83. https://doi.org/10.24014/jel.v11i1.10069.

Muzdalifa, I., Rahma, I. A., \& Novalia, B. G. (2018). Peran Fintech Dalam Meningkatkan Keuangan Inklusif Pada UMKM Di Indonesia (Pendekatan Keuangan Syariah). Jurnal Masharif Al-Syariah: Jurnal Ekonomi dan Perbankan Syariah, 3(1), Article 1. http://dx.doi.org/10.30651/jms.v3i1.1618.

Nafiah, R., \& Faih, A. (2019). Analisis Transaksi Financial Technology (Fintech) Syariah dalam Perspektif Maqashid Syariah. IQTISHADIA: Jurnal Ekonomi dan Perbankan Syariah, 6(2), 167-175. https://doi.org/10.19105/iqtishadia.v6i2.2479.

Nashrullah, N. (2019). Badan Bidik 30 Persen Transaksi Digital untuk Himpun ZIS | Republika Online. https://www.republika.co.id/berita/duniaislam/wakaf/19/02/11/pmrs0j320-badan-bidik-30-persen-transaksi-digital-untukhimpun-zis.

Nasrullah, N., Nawawi, K., \& Hamdani, I. (2020). Manajemen Pemasaran Lembaga Amil Zakat Nasional (Laznas) Studi Kasus: Baitul Maal Hidayatullah (Bmh) Pusat Jakarta. Al-Infaq: Jurnal Ekonomi Islam, 11(1), 100-109. https://doi.org/10.32507/ajei.v11i1.619.

Nurhadi, N. (2020). Collection of Zakat for Civil State Employees According to Islamic Law and Law. Indonesian Interdisciplinary Journal of Sharia Economics (IIJSE), 2(2), 114-124. https://doi.org/10.31538/iijse.v2i2.475

Nujaman, J. (2020, August 15). Zakat Online; Inovasi Berbasis Fintech untuk Optimalisasi Zakat di Indonesia. Islampos. https://www.islampos.com/zakat-online-inovasiberbasis-fintech-untuk-optimalisasi-zakat-di-indonesia-200467/.

Nurwati, N., \& Hendrawati, H. (2019). Zakat dan Upaya Mengentaskan Kemiskinan. Cakrawala: Jurnal Studi Islam, 14(1), 40-47. https://doi.org/10.31603/cakrawala.v14i1.2695. 
Purnama, N. I. (2017). Analisis Pengaruh Pertumbuhan Ekonomi Terhadap Tingkat Kemiskinan Di Sumatera Utara. Ekonomikawan: Jurnal Ilmu Ekonomi Dan Studi Pembangunan, 17(1), $62-70$. http://jurnal.umsu.ac.id/index.php/ekawan/article/view/1181.

Qodir, A. (1998). Zakat dalam Dimensi Mahdah dan Sosial. Raja Grafindo Persada.

Rachman, M. A., \& Salam, A. N. (2018). The Reinforcement of Zakat Management through Financial Technology Systems. International Journal of Zakat, 3(1), 57-69. https://doi.org/10.37706/ijaz.v3i1.68.

Rahman, M. R. (2019). Peran Zakat Dalam Mengentaskan Kemiskinan Di Indonesia. Hukum Islam, 19(2), 130-148. https://doi.org/10.24014/jhi.v19i2.8060.

Rahum, A. (2015). Pengelolaan Alokasi Dana Desa (ADD) Dalam Pembangunan Fisik Desa Krayan Makmur Kecamatan Long Ikis Kabupaten Paser. Ejournal Ilmu Pemerintahan, 3(4), 1523-1636. https://ejournal.ip.fisip-unmul.ac.id/site/wpcontent/uploads/2015/11/eJournal\%20(11-05-15-10-50-31).pdf.

Rencana-Strategis-Renstra-Baznas-2016-2020.pdf. (n.d.). Retrieved November 10, 2021, from https://pid.baznas.go.id/wp-content/uploads/2019/04/Rencana-StrategisRenstra-Baznas-2016-2020.pdf.

Rizal, M., Maulina, E., \& Kostini, N. (2019). Fintech sebagai Salah Satu Solusi Pembiayaan Bagi UMKM. AdBispreneur: Jurnal Pemikiran dan Penelitian Administrasi Bisnis dan Kewirausahaan, 3(2), 89-100. https://doi.org/10.24198/adbispreneur.v3i2.17836.

Safitri, J. (2018). Implementasi Konsep Zakat Dalam Al-Qur'an Sebagai Upaya Mengentaskan Kemiskinan di Indonesia. AT-TASYRI', 1-15. https://ejournal.staindirundeng.ac.id/index.php/Tasyri/article/view/32.

Salim, Abu Malik Kamal bin al-Sayyid. (2002). Sahih Fiqh Al-Sunnah Adillatuh wa Taudhih Mazahib al-Aimmah (Juz II). Al-Maktabah Al-Taufiqiyah.

Santi, E., Budiharto, B., \& Saptono, H. (2017). Pengawasan Otoritas Jasa Keuangan Terhadap Financial Technology (Peraturan Otoritas Jasa Keuangan Nomor 77/POJK.01/2016). Diponegoro Law Journal, 6(3), 1-20. https://ejournal3.undip.ac.id/index.php/dlr/article/view/19683.

Sawarjuwono, T., \& Kadir, A. P. (2003). Intellectual Capital: Perlakuan, Pengukuran Dan Pelaporan (Sebuah Library Research). Jurnal Akuntansi Dan Keuangan, 5(1), 3557. https://doi.org/10.9744/jak.5.1.pp.

Susanto, I., Heri, M., \& Fachrudin, A. (2019). Dampak Strategi Pemasaran Pariwisata terhadap Peningkatan Kesejahteraan Masyarakat dalam Perspektif Ekonomi Islam (Studi di Pantai Wisata Labuhan Jukung Krui Kabupaten Pesisir Barat). Syi ar Iqtishadi: Journal of Islamic Economics, Finance and Banking, 3(1), 114. https://doi.org/10.35448/jiec.v3i1.5518.

Tambunan, T. (1996). Perekonomian Indonesia. Ghalia Indonesia. 
Tim Penyusun Renstra Baznas. (2016). Rencana Strategis Zakat Nasional 2016-2020. Baznas.

Yudha, A. T. R. C., Saifuddin, M., Hilmi, A. F., \& Azzahra, A. (2021). Fintech Syariah dalam Sistem Industri Halal: Teori dan Praktik. Syiah Kuala University Press.

Yudhira, A. (2020). Analisis Efektivitas Penyaluran Dana Zakat, Infak dan Sedekah Pada Yayasan Rumah Zakat. VALUE, 1(1), 1-15. https://doi.org/10.36490/value.v1i1.87.

Zein, S. (2019). Tinjauan Yuridis Pengawasan Otoritas Jasa Keuangan Terhadap Aplikasi Pinjaman Dana Berbasis Elektronik (Peer To Peer Landing/ Crowfunding) di Indonesia. Jurnal Bisnis \& Akuntansi Unsurya, 4(2), Article 2. https://doi.org/10.35968/.v4i2.338. 